\title{
Evaluation of Potassium Leaching Potential of Wallace Sandstone From Nova Scotia in Acid Solution
}

\author{
Mumuni Amadu ${ }^{1}$, Adango Miadonye ${ }^{2}$ \\ ${ }^{1}$ Department of Process Engineering and Applied Science (PEAS), Dalhousie University, Halifax, Canada \\ ${ }^{2}$ School of Science and Technology, Cape Breton University, Sydney, Canada \\ Correspondence: Mumuni Amadu, Department of Process Engineering and Applied Science (PEAS), Dalhousie \\ University, Halifax, Canada.
}

Received: December 10, 2018 Accepted: January 20, 2019 Online Published: January 31, 2019

doi:10.5539/ijc.v11n1p18

URL: https://doi.org/10.5539/ijc.v11n1p18

\begin{abstract}
The increasing global demand for potassium fertilizer coupled with the uneven global distribution of potash has spurred global effort aimed at identifying feasible sources of geological resources that have the potential for supplement. Consequently, glauconitic sandstones have been studied in relationship to potassium leaching experiments to determine the feasibility of potassium supply for agronomical purposes.

In Nova Scotia, Wallace Sandstone is glauconitic, and it has been used extensively for building and construction purposes. In this paper, we have evaluated the potential for potassium release from Wallace Sandstone in acid solution at room temperature. We measured potassium release potential using solution $\mathrm{pH}$ versus time in addition to leached potassium after experiments. Results indicate measurable release of potassium from Wallace Sandstone samples.
\end{abstract}

Keywords: potassium, X-ray diffraction, diffusion, cation exchange, $\mathrm{pH}$

\section{Introduction}

Potassium $(\mathrm{K})$ is an essential requirement of plant nutrient normally found in low concentrations in tropical soils (Santos et al., 2016) and in view of its high demand for crop production, it is required in large amounts as fertilizer. However, few countries in the world are self-sufficient in the production of $\mathrm{K}$ fertilizers due to the limited natural geographical distribution of soluble $\mathrm{K}$ minerals, namely as sylvite, arcanite, carnallite, and langbeinite, with known deposits mainly found in the Northern Hemisphere (Manning, 2010). Countries noted for potassium deposits are Canada, Russia, Belarus, and Germany, with these countries accounting for approximately $85 \%$ of the K market worldwide (Lima and Neves, 2012; Ott, 2012).

Due to steady growth in world population (Sciences, 1963) potassium fertilizer consumption continues to increase every year. In light of uncertainties about the future market supply, some countries, such as Brazil, China, and India have directed research aimed at exploring domestic sources of K from silicates ores deposits (Eichler, 1983; Varadachari, 1992; Yadav and Sharma, 1992; Mazumder et al., 1993; Toledo Piza et al., 2011; Santos et al., 2015). Results of research have so far shown that there is potential for extracting $\mathrm{K}$ from minerals such as micas and feldspars (Santos et al., 2015).

In the literature, studies have been conducted on minerals of geologic origin as viable sources of potassium for agronomical purpose (Manning, 2010), notable among these minerals being glauconite from sandstone (Karimi, Abdolzadeh, Reza \& Aminei2012; Mazumder,Sharma and Rao, 1993; Shekhar, Mishra, Agrawal,\& Sahu2017). Karimi et al. (2012), based on the composition of $2.24 \%$ glauconite in sandstone have concluded that glauconite from sandstone has the ability to release potassium and can be utilized in combination with other potassium fertilizers. Santos et al., (2016), have also concluded from their studies that given the need for $\mathrm{K}$ fertilizer production, particularly in regions distant from sources of conventional products thermal and chemical treatments of verdete rock with $\mathrm{CaCl}_{2}$ as fluxing agents has the potential to modify insoluble $\mathrm{K}$ minerals to water-soluble $\mathrm{K}$ minerals, which can be of agronomic importance.

A review of literature on the potassium oxide content of glauconitic sandstones (Ibrahim, El Kammar,Guda ,Boulos and Saleh., 2018; Karimi et al., 2012; Shekhar et al., 2017; Turrentine et al., 1925; Amer and Sediek 2002) and comparison to that of Wallace Sandstone in Nova Scotia shows that the latter can be a potential source of glauconite. However, no report of potassium leaching experiments have been reported in any Canadian literature of extractive metallurgy. What is more, while other glauconitic sandstone that have been studied do not contain mica, Wallace sandstone contains mica in the 
form of sericite, which is an additional source of potassium. Therefore, our objective in this study is to explore the potential of Wallace Sandstone as a source of potassium for agronomical purposes, using the acid leaching method (Yadav and Sharma, 1992; Turrentine, Whittaker \& Fox1925; Amer and Sediek 2002).

Geochemically, Wallace Sandstone contains a high proportional of quartz in addition to glauconite. On the other hand, Fontainebleau Sandstone in France contains 99\% of silica (Chen, Li,Wang, Zhao, and Xiao 2016). Therefore, to embark on system study, a base line experimental control using Fontainebleau Sandstone which is mineralogically distinct with negligible glauconite and mica content will be considered.

\section{Mechanism of Potassium Release from Phyllosilicates}

\subsection{Potassium Release by Cation Exchange}

Cation exchange is a chemical process in which cations are exchanged equally between a solid, such as zeolite and a solution, such as water. The process is often used to soften water. Micaceous minerals belong to a class of phyllosilicates with structural characteristic, where a sheet of octahedral coordinated cation; Aluminum, Magnesium or Iron is sandwiched between sheets of linked tetrahedral (Perez-Rodriguez et al., 2006). Glauconite and muscovite are dioctahedral members of the micas (Melka, 2009). At low pH of aqueous solution, hydrogen ion replaces the framework cations and the order of replaceability is given as (Newman, 1969):

$\mathrm{Li}^{+}<\mathrm{Na}^{+}<\mathrm{K}^{+}<\mathrm{Rb}+<\mathrm{Cs}^{+}$et $\mathrm{Mg}^{+2}<\mathrm{Ca}^{+2}<\mathrm{Sr}^{+2}<\mathrm{Ba}^{+2}$

The cation exchange reaction can be written for a monovalent exchange reaction as (Chapelle \& Knobel, 1983):

$$
X_{a q}^{+}+Y . E x_{a d} \leftrightarrow Y_{a q}^{+}+X . E x_{a d}
$$

For glauconite this gives (Chapelle \& Knobel, 1983):

$$
\begin{aligned}
& \left(\mathrm{K}_{2}\left(\mathrm{Fe}_{1-x}, \mathrm{Mg}_{x}\right)_{2} \mathrm{Al}_{6}\left(\mathrm{SiO}_{10}\right)_{3}+(\mathrm{OH})_{12 \mathrm{~S}}+\frac{3}{2} \mathrm{O}_{2 g}+6 \mathrm{H}_{a q}^{+} \leftrightarrow 2 \mathrm{~K}_{a q}^{+}+2 x \mathrm{Mg}_{a q}^{+2}+6 \mathrm{SiO}_{2 a q}\right. \\
& +2(1-x) . \mathrm{Fe}(\mathrm{OH})_{3 S} \frac{3}{2} \mathrm{Al}_{4}\left(\mathrm{Si}_{4} \mathrm{O}_{10}\right)(\mathrm{OH})_{8 S}
\end{aligned}
$$

For muscovite this gives:

$$
2 \mathrm{KAl}_{3} \mathrm{Si}_{3} \mathrm{O}_{10}(\mathrm{OH})_{2(s)}+3 \mathrm{H}_{2} \mathrm{O}+2 \mathrm{H}_{(a q)}^{+} \rightarrow 1.5 \mathrm{Al}_{2} \mathrm{SiO}_{5}(\mathrm{OH})_{4(s)}+2 \mathrm{~K}_{(a q)}^{+}
$$

Cation exchange or potassium exchange reaction between micas and solution results in decreases in a net negative charge of the aluminosilicate layer and the net effect is that the absorbed metal cations in electrolyte solutions do not balance the potassium release into solution. The oxidation of iron 2 also reduces layer charge. These side reactions have effects on potassium release by decreasing the layer charge, which weakens the binding of potassium ions in the frame work structure.

Several sources of hydrogen ions for the above reactions have been proposed in the geochemical literature. One of this involves the supply of hydrogen ions from the oxidation of organic matter by sulfate reducing bacteria and the production of carbon dioxide through this reaction (Huggett, 1996). Another source of hydrogen ion is the decay of organic matter in sediment leading to the formation of carbon dioxide (Huggett, 1996)

\subsection{Diffusion Model of Potassium Release from Phyllosilicates}

The diffusion process of potassium release from phyllosilicates is related to acid induced dissolution of silicates (Crundwell, 2014), where the phyllosilicate framework is destroyed. Potassium should be more readily released from micas in acidic solutions by diffusion and this has been suggested by several publications (Scott, 1962; Dreher \& Niederbudde, 1994; Sarikhani, Khoshru and Oustan2016) By considering a unit mass of mica particle the application of Fick's to potassium diffusion gives (Scott, 1962):

$$
\frac{\partial Q}{\partial t}=D\left(\frac{\partial C}{\partial r}\right)_{b} A_{c}
$$


$Q, D, C, t, r, A_{c}$ are mass of potassium remaining at a particular time $\mathrm{t}$, diffusion coefficient, concentration of potassium in the diffusion path, time, radial distance and cross sectional area of the diffusion path respectively.

The analytical solution to Eq. (3), using Crank (1965) approach based on the appropriate boundary conditions leads to the following relationship between the amount of potassium $Q$, remaining in the octahedral framework of mica and time, $t$ (Scott, 1962):

$$
Q\left(1-\ln \frac{Q}{Q_{o}}\right)=Q_{o}-\frac{4 \tau D\left(C_{a}-C_{b}\right)}{\rho \delta r_{b}^{2}} t
$$

In this equation, $r_{a}, C_{b} C_{a}, C_{b} \mathrm{~A}$ weathering front within the mica particle from which the potassium diffuses is assumed to have a radial distance of $r_{a}$. Within the region $r<r_{a}$, the concentration of potassium will be constant and equal to that of the original particle, where $r$ is the instantaneous radius of the diffusion front. $r_{b}$ is the radius of a mica disc. Within the region $r_{a}<r<r_{b}$ is the weathered region of the particle and the zone where potassium diffusion occurs.

Potassium is, therefore, released from $r_{a}$ to $r_{b} . C_{a}$ and $C_{b}$ are the concentrations of potassium at radial distances $r_{a}$ and $r_{b}$ respectively. As potassium release continues, the weathering front recedes and $r_{a}$ decreases. The mathematical model amounts to a two dimensional radial diffusion problem with a moving boundary causing potassium release from a micaceous particle. In this study, we will test potassium release from Wallace Sandstone sample based on the diffusion or dissolution model, using experimental approaches.

\section{Mineralogy of Studied Rocks}

\section{Wallace Sandstone}

Wallace Sandstone is greyish to greenish-gray in color with specs of fibrous shiny looking mineral, which is sericite (reference-fibrous nature of sericite) (See Figure 1). Table 1 shows the oxide analysis results carried out by Dalhousie University Minerals Engineering laboratory. The table shows potassium oxide is the fourth most abundant in the analysis result.

Results of mineral analysis carried out by Dalhousie University (Mineral Engineering Center) Halifax, Nova Scotia. February 19th, 2001. (Quarry, 1967)

$\mathrm{SiO}_{2}$ Silicon Dioxide "Silica": $82.00 \%$

$\mathrm{Al}_{2} \mathrm{O}_{3}$ Aluminium Oxide "Alumina: $8.12 \%$

$\mathrm{Fe}_{2} \mathrm{O}_{3}$ Ferric Oxide "Hematile":3.19\%

$\mathrm{Na}_{2} \mathrm{O}$ Sodium Oxide: $1.67 \%$

$\mathrm{K}_{2} \mathrm{O}$ Potassium Oxide: $1.13 \%$

$\mathrm{MgO}$ Magnesium Oxide: $0.72 \%$

$\mathrm{CaO}$ Calcium Oxide: $0.81 \%$

TiO Titanium Oxide "Titania": $0.29 \%$

MnO Manganese Oxide "Magnesia" $0.10 \%$

Loss on Ignition $2.59 \%$ 


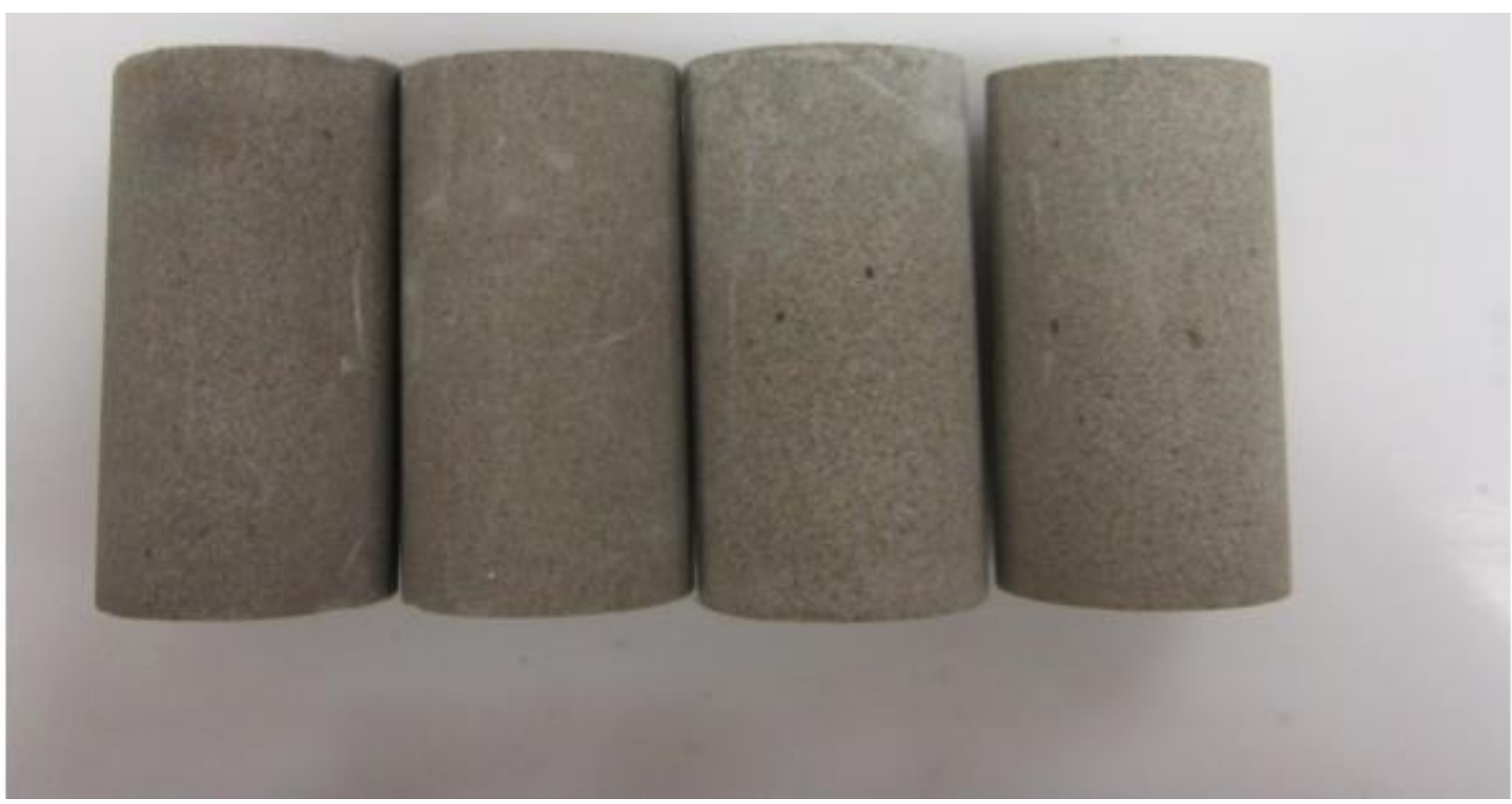

Figure 1. Wallace Sandstone core sample

\section{Fontainebleau Sandstone}

Fontainebleau sandstone samples look milky-white and fine grained (See Figure 2). They are composed of 99.9\% quartz and little clay minerals $(<0.1 \%)$ exist based on the results of X ray diffraction and scanning electron microscope (Chen $e t$ al., 2016).

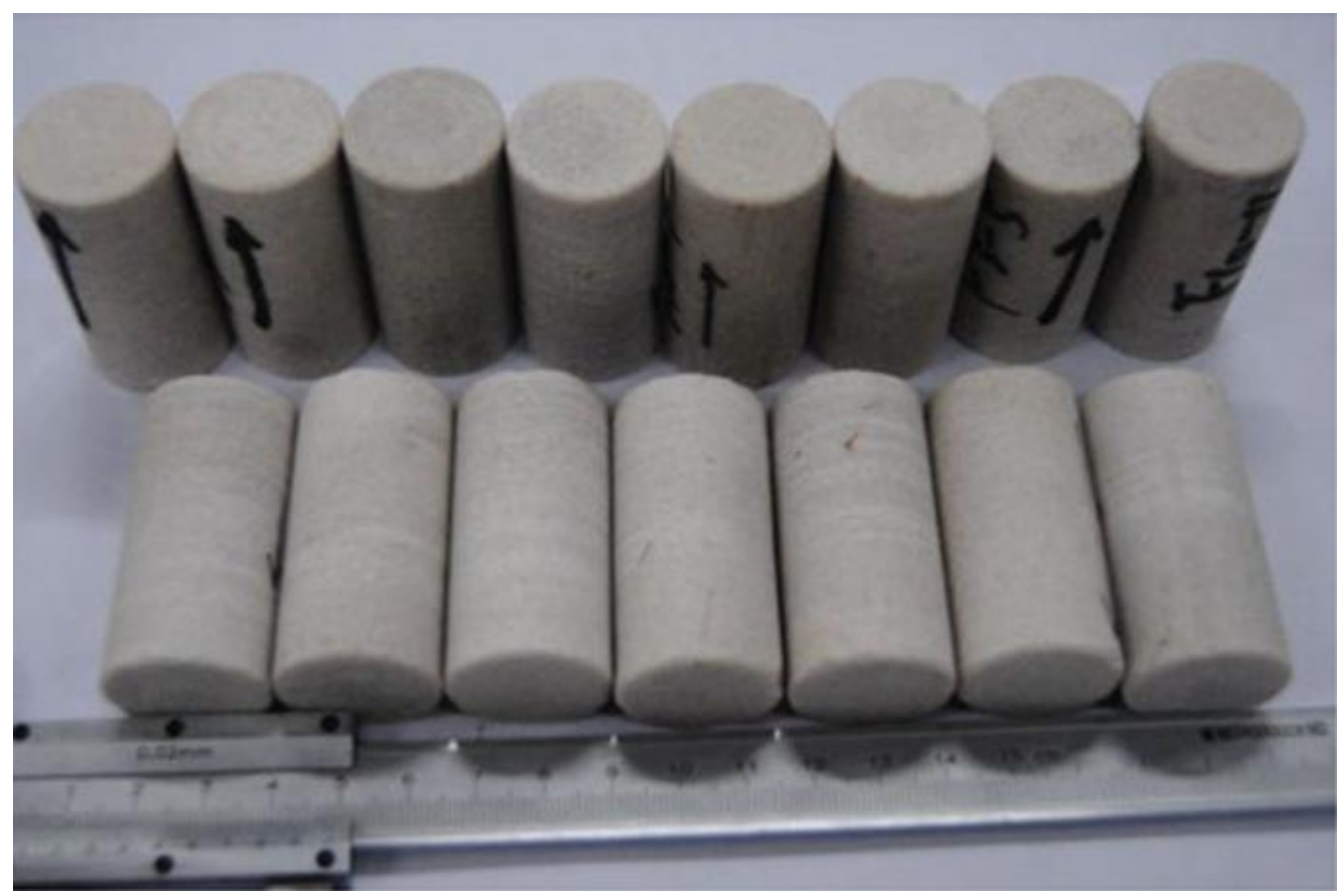

Figure 2. Fontainebleau Sandstone core samples

Based on X-ray diffraction analysis, Saadi, Wolf \& Kruijsdijk (2017 have also report the silica content of Fontainebleau Sandstone to be 0.995 . In all cited cases, the proprtion of clay minerals that are likely to produce potassium in acid leaching is negligible and this makes Foantainebleau Sandstone a suitable sample for control experiments regarding potassium leaching from Wallace Sandstone in acid solution, which contains significant potassium.

\subsection{Sample Characterization}

\subsubsection{X-ray Powder Diffraction Analysis of Wallace Sandstone}

The X-ray powder diffraction analysis was done using the materials science engineering laboratory of Dalhousie 
University Department of Chemical Engineering. The Bruker X-ray diffraction system with copper tube was used with $40 \mathrm{keV}$ with an X-ray wave length of 1.54 Angstrom. The objective of this characterization was to detect tectosilicates (feldspar and quartz) (Nesse, 2019) and phyllosilicates (micaceous minerals) (Nesse, 2019). Figure 3 below shows a plot of 2 theta versus intensities of mineral components in the sample.

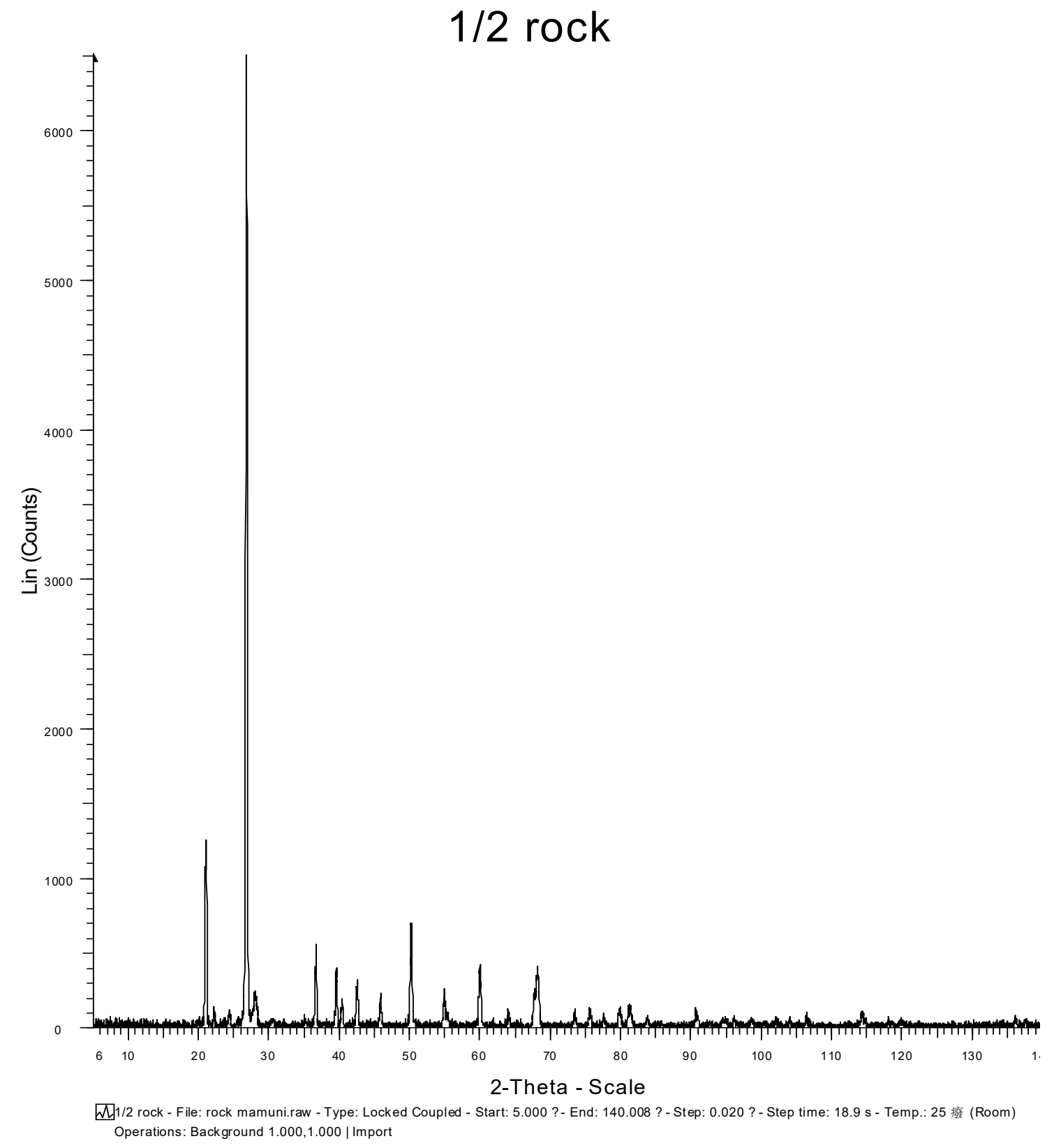

Figure 3. Results of X-ray powder diffraction analysis of Wallace Sandstone

\subsubsection{Carbonate Analysis of Wallace Sandstone Sample}

Apart from detrital fractions of sedimentary rocks such as sandstones and carbonates, authegenic minerals formed through digenesis are common occurrences (Zhang, et al., 2017). The objective was to detect of authigenic minerals in the form of carbonate cement (calcium carbonate (calcite), magnesium carbonate (dolomite) or iron carbonate (siderite) in Wallace sandstone. In this regard, the chemical reaction accompanying the heating of an oxide is represented by the following equation (Stuart Boyd, 1997):

$$
\mathrm{MCO}_{3} \rightarrow \mathrm{MO}+\mathrm{CO}_{2}
$$

From Eq. (5), produced carbon dioxide can be used as sufficient indication of carbonate presence in a given rock 
sample.

Total carbon analysis was done using Eltra CS 2000 Carbon Sulfur Determination PC Controlled equipment at the Minerals Processing Laboratory of Dalhousie University. The following table sums up analysis results.

Table 1. Results of carbon analysis for carbonate presence

\begin{tabular}{l|r|r}
\hline & \multicolumn{2}{|c}{ Weight percent \% } \\
\hline Sample & C (total) & \multicolumn{1}{c}{ C (Organic) } \\
\hline $\mathrm{CO}_{2}$ sample & 0.049 & 0.044 \\
\hline WSS \# 1 & 0.044 & 0.046 \\
\hline WSS \# 2 & 0.046 & 0.051 \\
\hline
\end{tabular}

\subsection{Experimental Design for Potassium Leaching in Acidic Solution}

\subsubsection{Materials and Equipment}

The source of mica for this experiment is glauconitic sandstone and quartz are nite (high percentage quartz bearing sandstone) core samples pulverized to 150 micrometer diameter using the mineral processing mill of the Mineral Processing Laboratory of Dalhousie University. The sandstone core samples are Wallace sandstone and Fontainebleau sandstone. This latter has a very small proportion of micaceous minerals.

\section{Experimental Procedure}

\subsection{Detection of Potassium Leaching Through pH Changes}

The glauconitic sandstone sample was crushed and ground to 152 micrometers using Jaw Crusher BB 50 Manufactured by Retsch. 2.2 grams of the pulverized sample was first weighed and put in $100 \mathrm{cc}$ of deionized water prepared using reverse osmosis. The mixture was vigorously stirred to obtain a uniform mixture. After a uniform mixture was obtained the initial $\mathrm{pH}$ corresponding to time zero was measure using the $\mathrm{pH}$ probe (Hanna HI98103) manufactured by ITM Instrument INC, which measures $\mathrm{pH}$ to one decimal place. A stop watch was started after the first $\mathrm{pH}$ reading and the $\mathrm{pH}$ of the aqueous solution was measured every two minutes interval. This procedure was repeated for Fontainebleau sandstone sample. In addition to the 2.2 grams sample test, a 10 gram sample test was also conducted for both sandstone samples. Although our choice of sample weight is arbitrary the 2.2 grams sample test is half of what was used by Yadav et al., 2000 in their experiment.

\subsection{Potassium Analyses Results}

Detection of potassium concentration increases in aqueous solution was possible comparing initial and final potassium concentrations of initial mixture and mixture after experiments, which was detected from constant values of measured pH versus time. The Varian Vista-Pno Simultaneous ICP-OE at the Minerals Processing Laboratory of Dalhousie University was used for initial and final potassium concentration measurements.

\subsection{Results and Discussion}

Diffraction is a phenomenon that is encountered when waves interact with materials that have regular spacing within their structure that are comparable to the wave length of the interacting wave. The phenomenon therefore occurs in the crystalline structures of geological minerals when they are subjected to X-rays because the wavelength of X-rays is of orders comparable to interatomic distances in crystalline minerals. In the field of $\mathrm{x}$-ray diffraction analyses when certain geometrical constraints are met, $\mathrm{x}$-rays interacting with minerals crystals will interfere constructively to produce a diffraction pattern.

Figure 3 shows results of X-ray Diffraction analysis obtained using powdered Wallace sandstone sample while Appendix A shows micrograph image of glauconite in the sample with explanations. Appendix B shows the Scanning Electron Microscopy image. Appendix C (Katsutoshi Tomita, 1988) shows X-ray diffraction results for mica where one of the peaks occurs at 5.3 Angstrom. Normally mica show high intensity at interatomic spacing of 5 Angstrom and this is visible in Figure 3. Appendix D (Porrenga, 1968) shows results for glauconite powder from literature sources. This gives peaks coinciding with twice the diffraction angle at 10,18, and 28. Comparison of these diffraction patterns to the analysis done using Wallace sandstone powder shows that at twice the diffraction angle equal to 28 there is a peak corresponding to glauconite.

In all, two samples of Wallace Sandstone were submitted to the Minerals Laboratory of Dalhousie University for carbonate analysis. The aim was to obtain conclusive evidence for calcite or siderite composition of this rock. The result, as seen in Table 1 shows that carbonate presence is not conclusive because of the low values of the analytical results for both samples (Wallace sample 1 and Wallace sample 2) 
Figure 4 shows plots of aqueous solution $\mathrm{pH}$ versus time for experiments with Wallace sandstone and Fontainebleau sandstone powder for an initial solution $\mathrm{pH}$ of 5.3 using 10 grams of each sample. The figure shows that at any time the curve for Wallace sandstone lies above that for Fontainebleau sandstone. This means that at any time, solution $\mathrm{pH}$ for Wallace sandstone experiments is higher than that for Fontainebleau sandstone. This observation is in line with the theory of acid induced silicate dissolution. Generally, all the silicate minerals dissolve by a common mechanism (Crundwell, 2014). The rates of dissolution of quartz at $25^{\circ} \mathrm{C}$ has been researched by a number of different research teams and the results suggest that quartz dissolves both in the acidic and in the alkaline region. The average order of reaction is 0.5 with respect to $\mathrm{H}^{+}$in the acidic region, and 0.5 with respect to $\mathrm{OH}^{-}$in the alkaline region (Brantley, 2004). This dissolution rate also applies to phyllosilicates with the same average reaction order. Table 2 of Brantley (2004) shows that the average order in acidic solution regarding phyllosilicates (e.g. Muscovite) is 0.30 while that Tectosilicates (e.g. quartz) is 0.42. However, Table 4.2.1 of Arthur, Svage, Sasamoto, Shibata and Yui, 2000, shows that the rate constant for acid dissolution of quartz at $25^{\circ} \mathrm{C}$ is $10^{-13.8} \mathrm{~mol} \mathrm{~m}^{-2} \mathrm{sec}^{-1}$ while that for muscovite is $10^{-12.5} \mathrm{~mol} \mathrm{~m}^{-2}$ $\sec ^{-1}$

Therefore, quartz will dissolve at a slower rate in acid solution compared to muscovite. The implication is that in the mixture of Fontainebleau Sandstone, the instantaneous proton consumption rate will be lower compared to that of Wallace Sandstone, where glauconite and muscovite (phyllosilicates) occur. The curve for instantaneous $\mathrm{pH}$ versus time for Fontainebleau Sandstone will, therefore, lie below that of Wallace Sandstone because of higher proton consumption rate in the latter mixture leading to faster $\mathrm{pH}$ increase of the mixture.

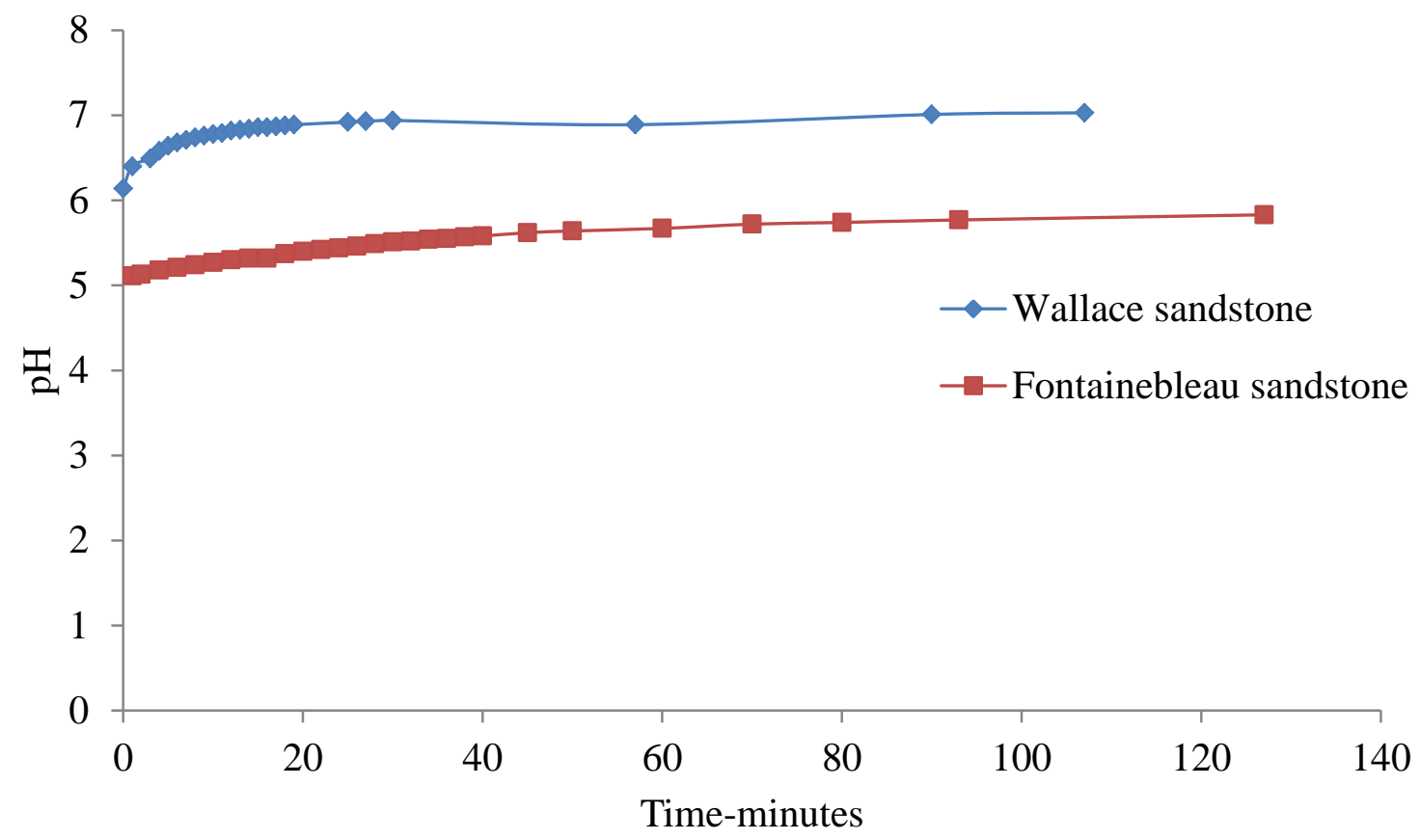

Figure 4. Measured $\mathrm{pH}$ versus time 10 grams of each sample in aqueous solution

The two curves start at $\mathrm{pH}$ value higher that the initial $\mathrm{pH}$. This is because after mixing deionized water with 10 grams of powder, the mixture was vigorously stirred in order to obtain a uniform mixture before $\mathrm{pH}$ reading. During the stirring time ( 3 minutes), there was level of silicate dissolution and this resulted in $\mathrm{pH}$ changes.

The curve for Fontainebleau sandstone shows that there is a certain level of silicate dissolution at a very slow rate, which could be caused by accessory minerals and this observation confirms the X-Ray characterization results of (Chen et al., 2016) which reports less than1 percent clay in addition to predominant quartz.

Figure 5 shows other plots of mixture transient hydrogen ion concentration versus time. To derive transient hydrogen ion concentration the mathematical definition of $\mathrm{pH}$ was employed (Bates, 1948). According to the explanation given before in line with silicate dissolution theory, the curve for Fontainebleau lies above that for Wallace because of the high transient hydrogen ion concentration compared to that of Wallace sandstone. 


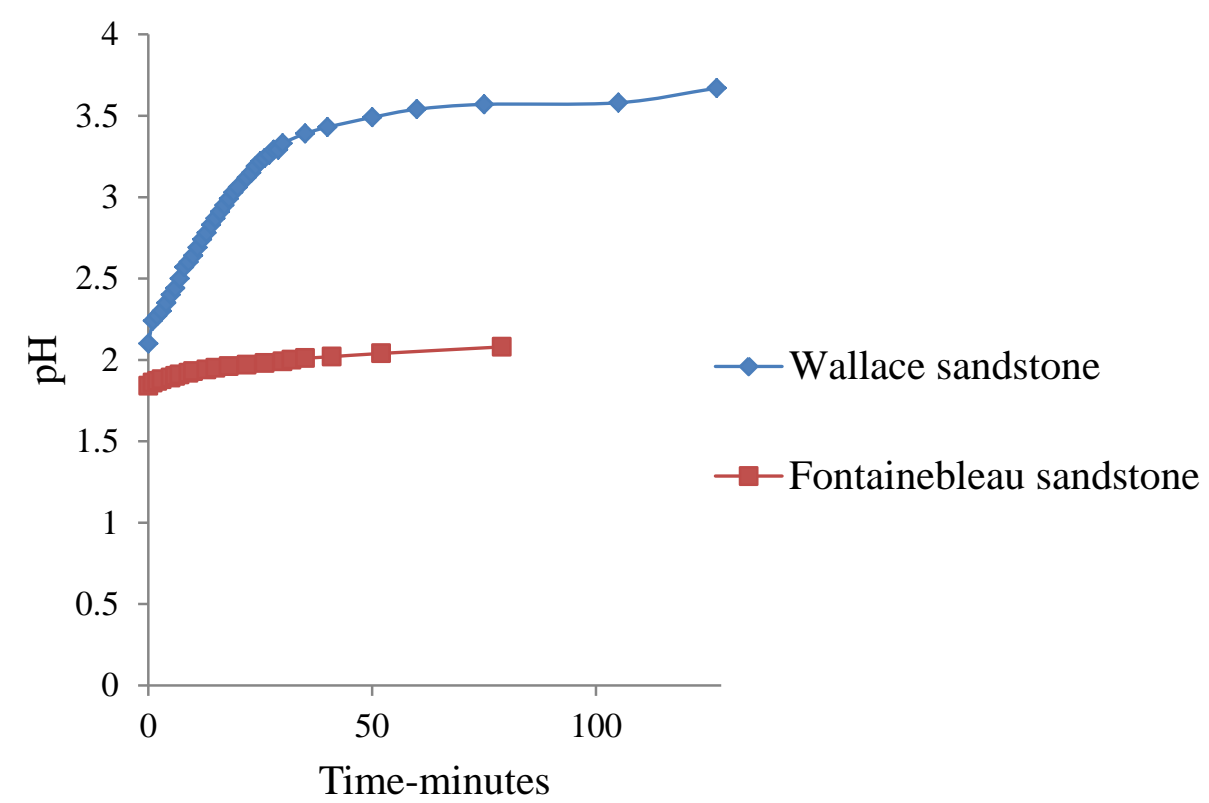

Figure 5. Transient hydrogen ion concentration versus time $\mathrm{pH} 5.37$

Figure 6 shows plots of transient $\mathrm{pH}$ versus time for bot rock samples similar to Figure 4 with trends that can be explained as before.

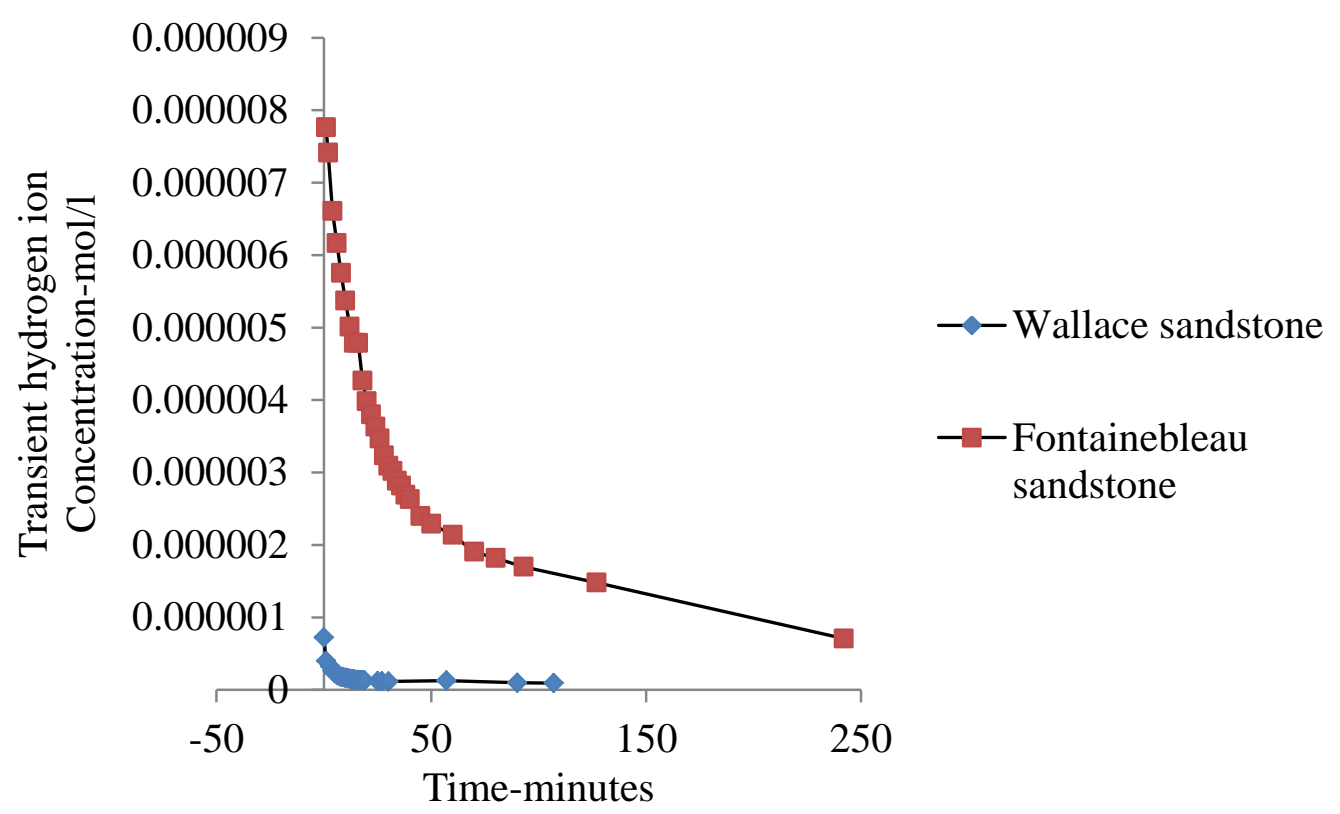

Figure 6. Measured $\mathrm{pH}$ versus time 10 grams of each sample with an initial $\mathrm{pH}$ of 1.76

Figure 7 shows plots of transient $\mathrm{pH}$ versus time. Figure 8 shows plots for transient $\mathrm{pH}$ versus time while Figure 9 shows plots of Transient hydrogen ion concentration versus time, all based on different weights of sample and initial mixture $\mathrm{pH}$, where observed trends can be explained as before. 


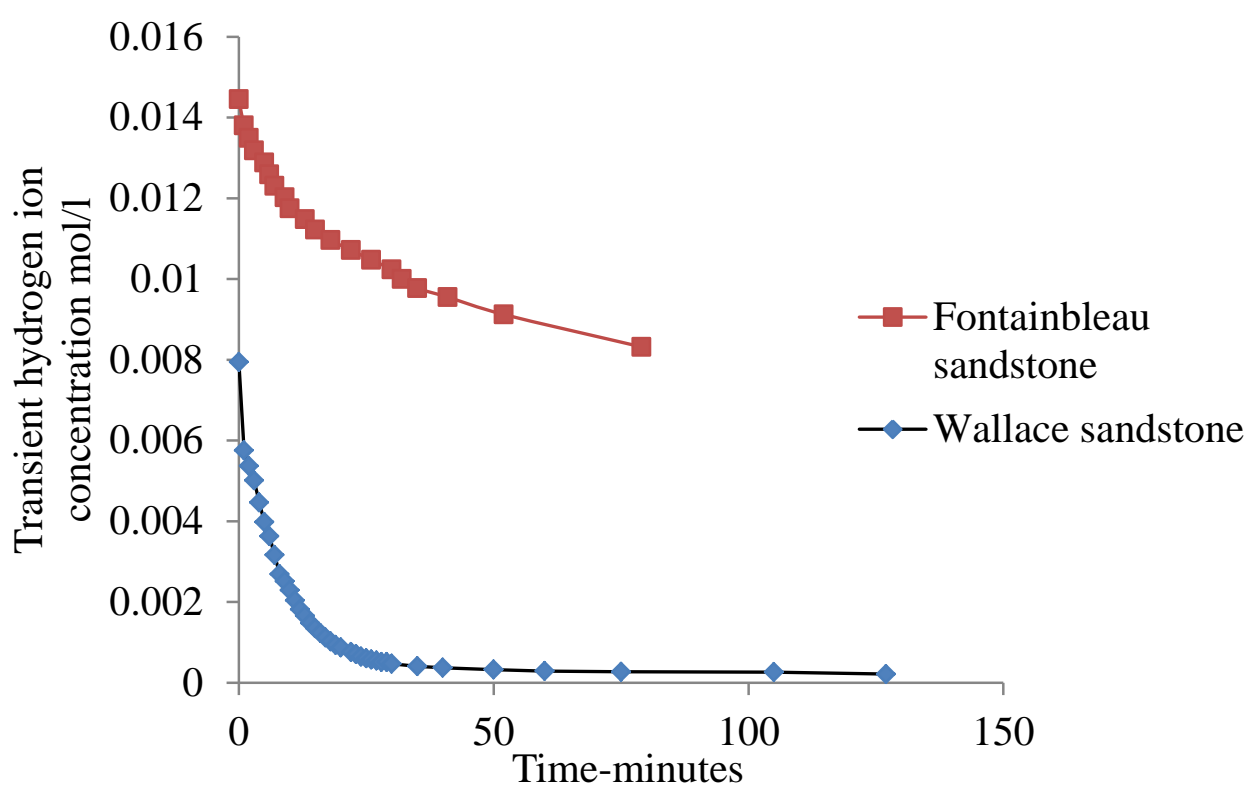

Figure 7. Transient hydrogen ion concentration versus time for equal to $\mathrm{pH} 1.76$ using 10 grams of sample

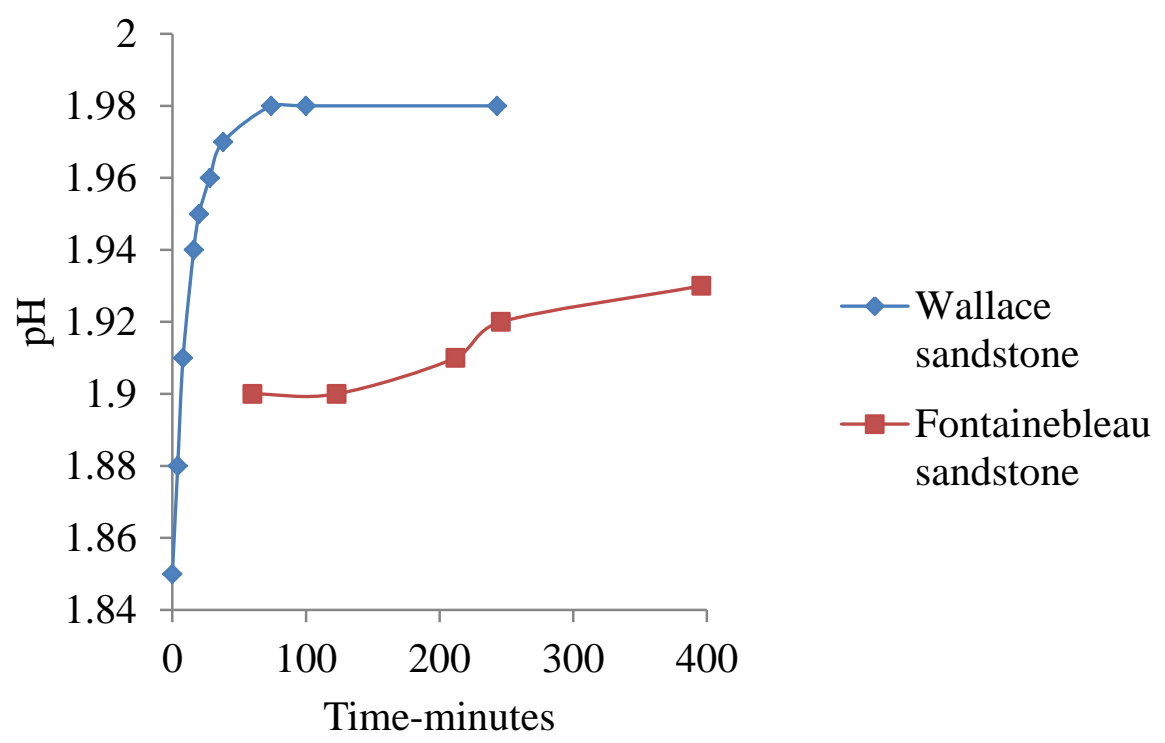

Figure 8. Measured $\mathrm{pH}$ versus time 2.2 grams of each sample with an initial $\mathrm{pH}$ of 1.76 


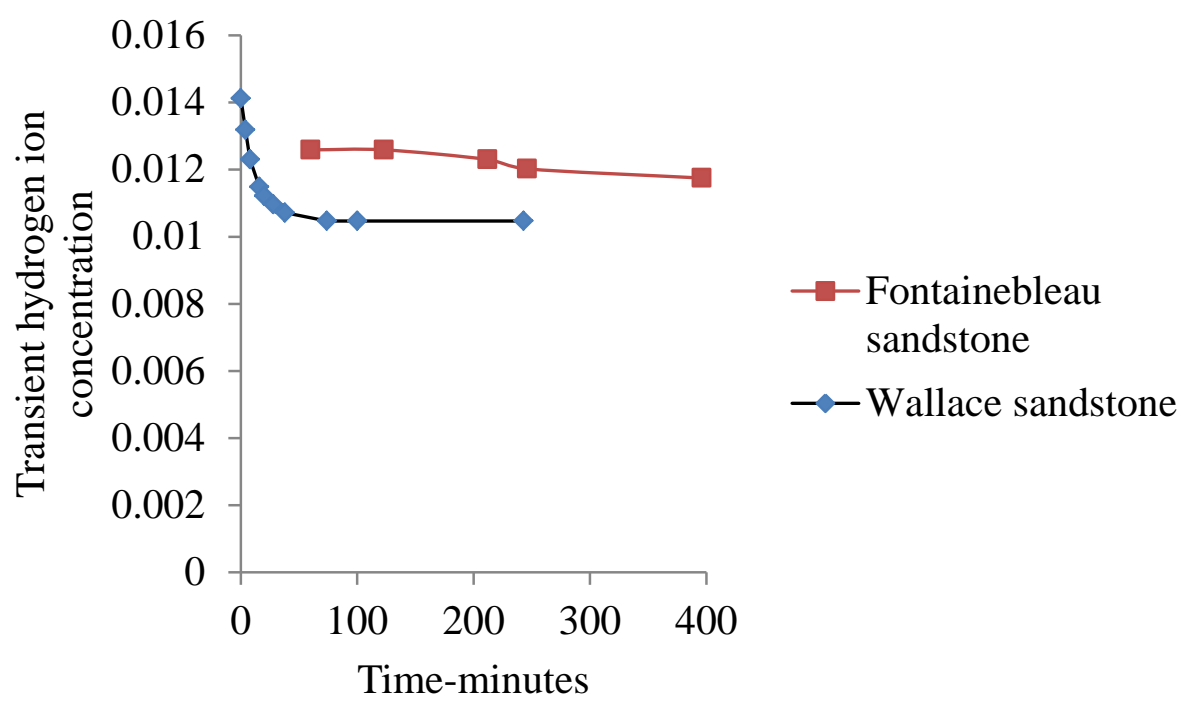

Figure 9. Transient hydrogen ion concentration versus time $\mathrm{pH} 1.76$ for 2.2 grams of samples in aqueous solution

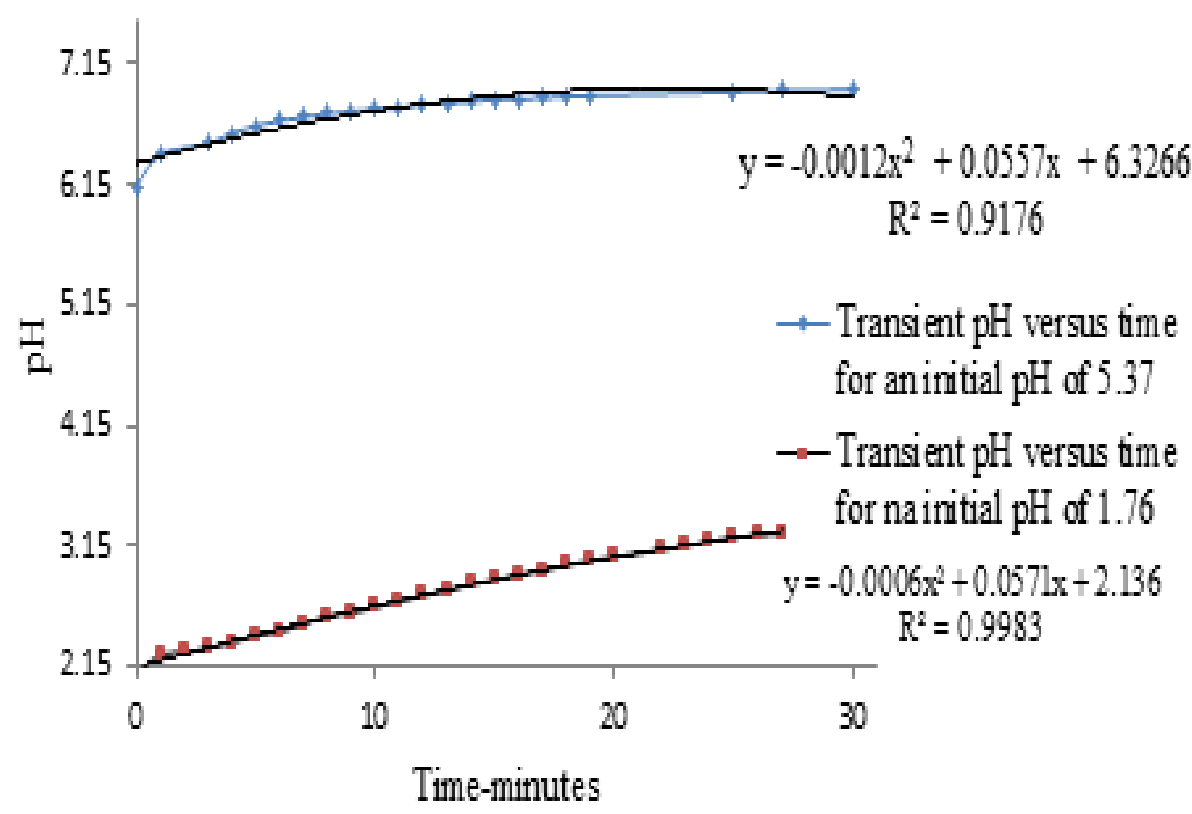

Figure 10. Combined plot of transient $\mathrm{pH}$ of aqueous solution versus time for Wallace sandstone at different initial $\mathrm{pH}$ of aqueous solution

Figure 10 shows plots of transient $\mathrm{pH}$ versus time for both Wallace and Fontainebleau Sandstones with a second degree polynomial fits

The regression coefficients are appreciably higher. Accordingly, the gradient functions of the plots can be used to compare the rate of $\mathrm{pH}$ increase for each experiment. Accordingly, the gradient functions are given as:

Wallace Sandstone:

$\frac{d p H}{d t}=-0.0028 t+0.0557$

For Fontainebleau Sandstone

$\frac{d p H}{d t}=-0.0012 t+0.0571$

The gradient functions show that at a given time, the rate of $\mathrm{pH}$ increase for Wallace Sandstone is higher compared to 
that for Fontainebleau Sandstone because of faster potassium release reaction, which consumes protons at a faster rate.

Wallace sandstone has greyish green color which is due to the presence of glauconite (Velde, 2003). In addition, visual inspection of a sample of the rock shows the presence of flaky minerals that are shiny in appearance. These latter minerals are micaceous mineral called muscovite. Both muscovite and glauconite have frame work cations as potassium. Also, the feldspar content of sandstones can be sources of potassium. The micaceous minerals are capable of dissolution and release of potassium by diffusion (Kuwahara \& Aoki, 1995). In this regard, (Yadav, Sharma \& Saxena2000) have reported potassium dissolution reaction from glauconitic sandstones using dilute solutions of hydrochloric acid, nitric acid and sulfuric acid similar to that used in this study.

\subsection{Potassium Analysis}

In order to test for potassium presence in deionized water after the addition of acid and pulverized samples of rocks, the mixtures were filtered and filtrates were taken for analysis. Table 2 shows results of potassium analyses. From the table, initial mixture analysis without acidifying gave 3.39 milligram of potassium per liter for Wallace Sandstone. This was taken as the base line value. Acidified brine mixture of Wallace sandstone sample gave 29.5 milligrams of potassium per liter. A repeated analysis gave 27.5 milligrams per liter. The result for pulverized Fontainebleau sandstone sample gave 9.6 milligrams per liter after acidifying.

The result of potassium analyses is, therefore, quite conclusive that potassium release from minerals in all samples into solution is possible, with that of Wallace Sandstone showing exceptionally higher concentration. The exceptionally higher value for Wallace Sandstone resulted in higher values of instantaneous mixture solution $\mathrm{pH}$ in the plots (see Figures 4,6 and 8 Results of potassium analyses in the case of Fontainebleau is very low and this points to almost negligible potassium content as reported by Chen et al., (2016)

Table 2. Results of potassium analysis

\begin{tabular}{|c|c|}
\hline Sample & Potassium concentration $\mathrm{mg} / \mathrm{l}$ \\
\hline Acidified Brine & \multirow{3}{*}{$28.5,27.5$} \\
\hline Acidified brine with pulverized Wallace sandstone & \\
\hline Acidified brine with pulverized Fontainebleau sandstone & \\
\hline
\end{tabular}

The potential of glauconite as raw material for the production of fertilizer has long been reported by the Ministry of Foreign Affairs of the United States (Curtis, 1924). Among countries that have reported the potential for acid leaching of potassium from glauconitic sandstone deposits for fertilizer purposes are (see Table 3) India (Yadav et al., 2000), Iran (Karimi et al., 2012), Tunisia (Erraioui, Srasra, Zargouni,Tajeddin, 2005), Quebec-Canada (Cousineau \& Pierre, 2006), Argentina (Tourn \& Castro, 2003) and Egypt (Ammer \& Sediek,, 2003). Actually, the glauconitic potential of sandstone for potassium leaching purposes will be supported by the Oxide analysis. The results of the oxide analyses must show a high percentage by weight of potassium oxide because of the occurrence of targeted potassium in the octahedral framework of glauconite (Thompson, 1975). The following table gives data extracted from countries with notable potential for acid leaching of glauconite from glauconitic sandstones in addition to data obtained from the analysis of Wallace sandstone sample for construction purposes in Nova Scotia.

Table 3. Potassium oxide concentrations (\%) from glauconitic sandstones from literature

\begin{tabular}{l|l|l}
\hline Country & $\begin{array}{l}\text { Potassium oxide } \\
\text { composition (\%) }\end{array}$ & Reference \\
\hline Quebec (Canada) & 8.58 & (Cousineau \& Pierre, 2006) \\
\hline India & 5.4 & $\begin{array}{l}\text { (Yadav, Sharma, \& Saxena, Dissolution kinetics of potassium from } \\
\text { glauconitic sandstone in acid lixiviant, 2000) }\end{array}$ \\
\hline Egypt & 4.17 & (Ammer \& Sediek,, 2003) \\
\hline Iran & 2.24 & (Ehsan Karimi, 2012) \\
\hline $\begin{array}{l}\text { Wallace sandstone } \\
\text { (Nova Scotia) }\end{array}$ & 1.13 & http://www.wallacequarries.com/test-data.html \\
\hline
\end{tabular}

The result shows that Quebec in Canada has the highest potential followed by India. The next is Egypt. Iran is the last, but the one with Wallace in Nova Scotia being at the bottom with potassium oxide concentration by weight of 1.13. All these countries except Nova Scotia where no acid leaching of potassium has been scientifically investigated at 
conditions typical of industrial environments have the hope of embarking on commercial leaching of potassium form glauconitic sandstones

\section{Conclusion}

In this study, the potential of Wallace sandstone as a viable source of potassium leaching for the agroindustry has been investigated at room temperature and compared with that of a purely quartz arenite sandstone (Fontainebleau), where the proportion of micaceous minerals is negligible. The following sum up the conclusion of this study:

1. Results of acid leaching of potassium from Wallace sandstone under laboratory conditions show measurable concentrations of leached potassium in aqueous solutions,

2. In addition to the potassium leaching results, X-ray diffraction analysis and carbonate analysis on Wallace sandstone samples confirm the presence of glauconite and absence of carbonate respectively,

3. We have also compared oxide analysis of this sandstone sample carried out by the Mineral Engineering Laboratory of Dalhousie University with those of countries with notable potential for potassium leaching from glauconitic sandstones. Although, results for Wallace sandstone is at the bottom of the table, the value for Iran with a potential of 2.24 is not too far from that of Wallace sandstone (1.13). This difference is not too much to rule out the potential for Wallace sandstone,

4. In view of the positive correlation between silicate dissolution rate and temperature, leaching of potassium from Wallace Sandstone at temperatures typical of commercial processes will yield more potassium than the room condition leaching Therefore, the conclusion of the present study is that Wallace sandstone is appreciably a potential source of potassium that can be reached for agricultural purposes.

\section{Future work}

In view of the room temperature conditions of this study, there is the need for the potassium leaching potential of Wallace Sandstone to be investigated further by imposing experimental conditions typical of industrial environments. What is more, the results of the present study should give impetus for intensive research into potassium leaching potential from Wallace sandstone. The result of this study should also be an indicator to the Scotian community, regarding the importance of this sandstone for the agroindustry. In this regard, we intend to do additional oxide analysis using different samples of Wallace sandstone with the view to reporting the average value of potassium oxide concentration from several samples of this sandstone obtained from different locations and depths.

\section{Acknowledgements}

In carrying out this research work related to the potential of potassium leaching from Wallace Sandstone samples from Nova Scotia, we owe much of our success, particularly the timely completion, to the document delivery sections of Dalhousie University and Cape Breton University. We also wish to acknowledge the contribution of the Mineral Engineering Laboratory of Dalhousie University for making available test results on time.

\section{References}

Amer, A. M., \& Sediek, K. N. (2002). Compositional and Technological Characterization of Selected Glaucony Deposits of North Africa. Physicochemical Problems of Mineral Processing, 37, 159-168.

Ammer, A. M. S. K. (2003). Compositional and Technological CharacteristicsofF Selected Glaucony Deposits of North Africa. Physicochemical Problems of Mineral Processing, 37, 159-168.

Arthur, R. C., Savage, D., Sasamoto, H., Shibata, M., \& Yui, M. (2000). Compilation of Kinetic Data for Geochemical Calculations. Japan Nuclear Cycle Development Institute, 1-61. https://doi.org/10.1021/cr60131a001

Bates, R. G. (1948). Definitions of pH Scales. Chem. Rev., 42(1), 1-61.

Brantley, S. (2004). Reaction kinetics of primary rock-forming minerals under ambient conditions. In: Drever, J.I. (Ed.), Surface and Ground Water, Weathering, and Soils, 5, 73-118.

Chapelle, F. H., \& Knobel, L. L. (1983, May). Aqueous Geochmeistry and the Exchangeable Cation Composition of Glauconite in the Aquia Aquifer, Maryland. Ground water, 21(3), 343-352. https://doi.org/10.1111/j.1745-6584.1983.tb00734.x

Chen, M., Li, M., Wang, Y., Zhao, J. Z., \& Xiao, W. L. (2016). The Permeability of Fontainebleau Sandstone to Gases and Liquids. 34(9), 845-852. https://doi.org/10.1080/10916466.2016.1172087

Cousineau, H. L., \& Pierre, A. (2006). Constraint on the Genesi of Ferrian Illite and Aluminum-Rich GlauconiteE: Potential Impact on Sedimentology and Isotopic Studies. The Canadian Mineralogist, 44, 967-980. https://doi.org/10.2113/gscanmin.44.4.967 
Crank, J. (1965). The Mathematics of Diffusion. Oxford at the Clarendon Press.

Crundwell, F. (2014). The mechanism of dissolution of minerals in acidic and alkaline solutions: Part II Application of a new theory to silicates, aluminosilicates and quartz. Hydrometallurgy, 149, 265-275. https://doi.org/10.1016/j.hydromet.2014.07.003

Curtis, H. (1924, March). Fertilizers: The World Supply. Foreign Affairs, 2(3), 436-445. https://doi.org/10.2307/20028312

Dreher, P., \& Niederbudde, E. (1994). Potassium Release from Micas and Characterization of the Alteration Products. Clay Minerals, 29, 77-85. https://doi.org/10.1180/claymin.1994.029.1.09

Eichler, V. (1983). Disponibilidade do pota 'ssio do verdete de Abaete calcinado come sem calcario magnesiano, para a cultura do milhoem solos de textura me 'dia e argilosa. PhD thesis, Universidade Federal de Lavras, Brazil

Erraioui, L., Srasra, E., Zargouni, F., \& Tajeddin, K. (2005). Petrological and physico-chemical investigations on an Tunisian glauconitic deposi. J. Phys. IV France, 123, 71-74. https://doi.org/10.1051/jp4:2005123011

Huggett, J. (1996). Aluminosilicate Diagenesis in a Tertiary Sandstone-Mudrock Sequence from the Central North Sea. Clay Mineralogy, 31, 523-536. https://doi.org/10.1180/claymin.1996.031.4.10

Ibrahim, S. S., El Kammar, A. M., Guda, A. M., Boulos, T. R., \& Saleh, A. (2018). Characterization and Mineral Beneficiation of Egyptian Glauconite for Possible Industrial use. Particulate Science and Technology, 1-10. https://doi.org/10.1080/02726351.2017.1376019

Karimi, E., Abdolzadeh, S., Reza, H., \& Aminei, A. (2012). The Potential of Glauconitic Sandstone as a Potassium fertilizer for Olive Plants. Archives of Agronomy and Soil Science, 58(9), 983-993. https://doi.org/10.1080/03650340.2011.557369

Kuwahara, Y., \& Aoki, Y. (1995). Dissolution Process of Phlogopite in Acid Solutions. Clays and Clay Minerals, 43(1), 39-50. https://doi.org/10.1346/CCMN.1995.0430105

Lima, T. M., \& Neves, C. A. R. (2012): Suma '́rio Mineral 2012. DNPM, Brasilia, Brazil.

Manning, D. A. (2010). David A.C. Manning. Mineral sources of potassium for plant nutrition. A review. Agronomy for Sustainable Development, Springer Verlag/EDP Sciences/INRA, 2010, 30(2), <10.1051/agro/2009023>. $<$ hal-0088652. Agron. Sustain. Dev., 30, Agron. Sustain. Dev. .

Mazumder, A. K., Sharma, T., \& Rao, T. (1993). Extraction of Potassium from Glauconitic Sandstone by the Roast-Teach Method. International Journal of Mineral Processing, (38), 111-123. https://doi.org/10.1016/0301-7516(93)90068-L

Melka, K. (2009). A Scheme for the Classification of Micaceous Minerals. Acta Geodyn. Geomater., 6(1), 69-75.

Nesse, W. D. (2019). Introduction to Mineralogy-Second Edition. Oxford: Oxford University Press.

Newman, A. C. (1969, September). Cation Exchnage Properties of Micas. the Relation between Mica Composition and Potassium Exchnage in Soils of Different pH. Journal of Soil Science, 20(2), 357-372. https://doi.org/10.1111/j.1365-2389.1969.tb01584.x

Ott, H. (2012). Fertilizer markets and their interplay with commodity and food prices. JRC Scientific and Policy Reports, European Commission, Seville, Spain.

Pérez-Rodríguez, J., Wiewióra, A., Drapala, J., \& Pérez-Maqueda, L. (2006, January). The effect of sonication on dioctahedral and trioctahedral micas. Ultrasonics Sonochemistry, 13(1), 61-67. https://doi.org/10.1016/j.ultsonch.2004.12.001

Porrenga, D. (1968). Non-Marine Glauconite Illite in the Lower Oligocene of Aardebrug,Belgium. 7(421).

Quarry. (1967). Wallace Quarries - Test Data. Retrieved from Testing Data For Wallace Sandstone: http://www.wallacequarries.com/test-data.html

Saadi, F. A., Wolf, K. H., \& Kruijsdijk, C. V. (2017). Characterization of Fontainebleau Sandstone: Quartz Overgrowth and its Impact on Pore-Throat Framework. J. Pet Environ Biotechno., 8(3), 1-12. https://doi.org/10.4172/2157-7463.1000328

Santos, W. O., Mattiello, E. M., da Costa, L. M., \& Abrahão, W. A. (2015). Characterization of Verdete rock as a Potential Source of Potassium. Rev. Ceres, Viçosa, 62(4), 392-400. https://doi.org/10.1590/0034-737X201562040009

Santos, W. O., Vergutz, L., \& Costa, R. F. (2016). Production and Evaluation of Potassium Fertilizers from Silicate 
Rock. J. Plant Nutr. Soil Sci., 179, 547-556. https://doi.org/10.1002/jpln.201500484

Sarikhani, M. R., Khoshru, B., \& Oustan, S. (2016). Efficiency of Some Bacterial Strains in Potassium Release from Mica and Phosphate Solubilization under In Vitro Conditions. Geomicrobiology Journal, 33(9), 832-838. https://doi.org/10.1080/01490451.2015.1117548

Sciences, N. A. (1963). The Growth of World Population:Analysis of the Problems and Recommendations for Research and Training (1963). Washington, DC: The National Academies Press.

Scott, M. G. (1962, September). Kinetics of Potassium Release from Biotite and Muscovite in Sodium Tetraphenylboron Solutions. Soceity of Soil Science of American Journal, 26(5), 437-440. https://doi.org/10.2136/sssaj1962.03615995002600050010x

Shekhar, S., Mishra, D., Agrawal, A., \& Sahu. (2017). Physico-Chemical Treatment of Glauconitic Sandstone to Recover Potash and Magnetite. Journal of Cleaner Production, 147, 691-693. https://doi.org/10.1016/j.jclepro.2017.01.127

Stuart, B. I. W. (1997, January). Stepped-heating of carbonates and carbon-bearing quartz grains. Chemical Geology, 134(14), 303-310.https://doi.org/10.1016/S0009-2541(96)00099-X

Thompson, G. R. (1975). The Mineralogy of Galuconite. Clay and Clay Minerals, 23, 289-300. https://doi.org/10.1346/CCMN.1975.0230405

Tomita, K., Hidewo, T., \& Takahashi, W. (1988). Quantification Curves for Mica/Smectite Interstratifications by X-Ray Powder Diffraction, Clays and Clay Minerals, 26(3), 255-262. https://doi.org/10.1346/CCMN.1988.0360307

Tourn, L., \& Castro, S. (2003). Direct Application of Phosphate Rocks and Glauconite as Alternative Sources of Fertilizer in Argentina. Explor. Mining Geo, 12(1-4), 71-78. https://doi.org/10.2113/0120071

Turrentine, J. W., Whittaker, C. W., \& Fox, E. J. (1925). Potash from Greensand (Glauconite). Industrial and Engineerin Chemistry, 17(12), 1177-1181. https://doi.org/10.1021/ie50191a033

Varadachari, C. (1992): An investigation on the reaction of phosphoric acid with mica at elevated temperatures. Ind. Eng. Chem. Res. 31, 357-364. https://doi.org/10.1021/ie00001a048

Velde, B. (2003). In Treatise on Geochemistry-7.12 - Green Clay Minerals (Vol. 7, pp. 309-324).

Yadav, V., \& Sharma, T. (1992). Leaching of Glauconitic sand stone in acid lixiviants. Minerals Engineering, 5(6), 715-720. https://doi.org/10.1016/0892-6875(92)90066-I

Yadav, V., Sharma, T., \& Saxena, V. (2000, August). Dissolution kinetics of potassium from glauconitic sandstone in acid lixiviant. International Journal of Mineral Processing, 60(1), 15-36. https://doi.org/10.1016/S0301-7516(99)00083-6

Zhang, Y. L., Bao, Z. D., Zhao, Y., Jiang, L., Zhou, Y. Q., \& Gong, F. H. (2017). Origins of authigenic minerals and their impacts on reservoir quality of tight sandstones: Upper Triassic Chang-7 Member, Yanchang Formation, Ordos Basin, China. Australian Journal of Earth Sciences, 64(4), 519-536. https://doi.org/10.1080/08120099.2017.1318168 


\section{APPENDICES}
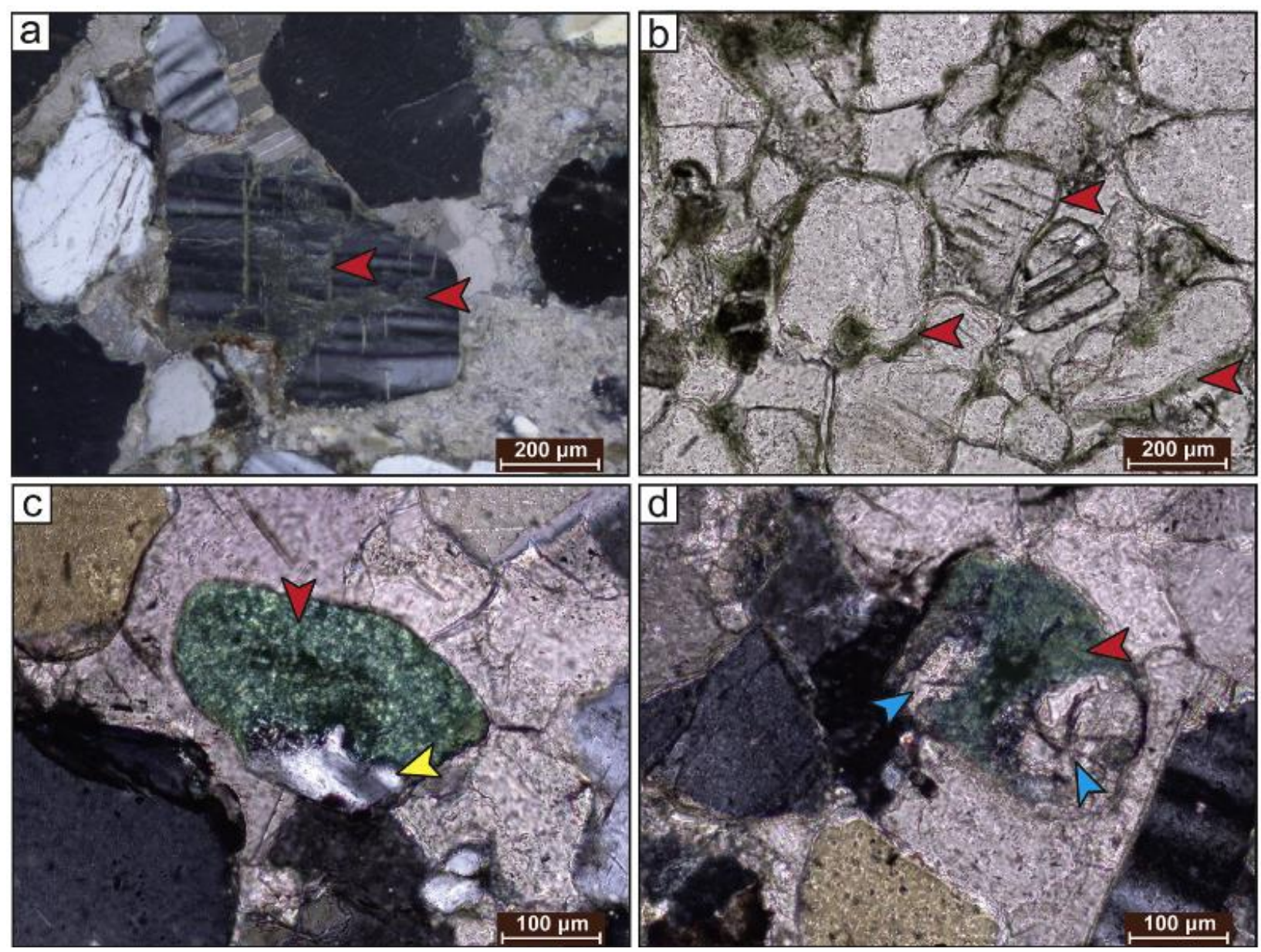

Appendix A: Micrograph image of the glauconite in the rock sample

Microphotographs under cross-polarized light showing A incipient glauconite within cleavages of K-feldspars (red arrows); B Glauconite rinds along peripheries of feldspar grains (red arrows); C Relict of feldspar substrate (yellow arrow) within a glauconite pellet (red arrow); Extensive calcite replacement (blue arrows) of a glauconite grain (red arrow) 


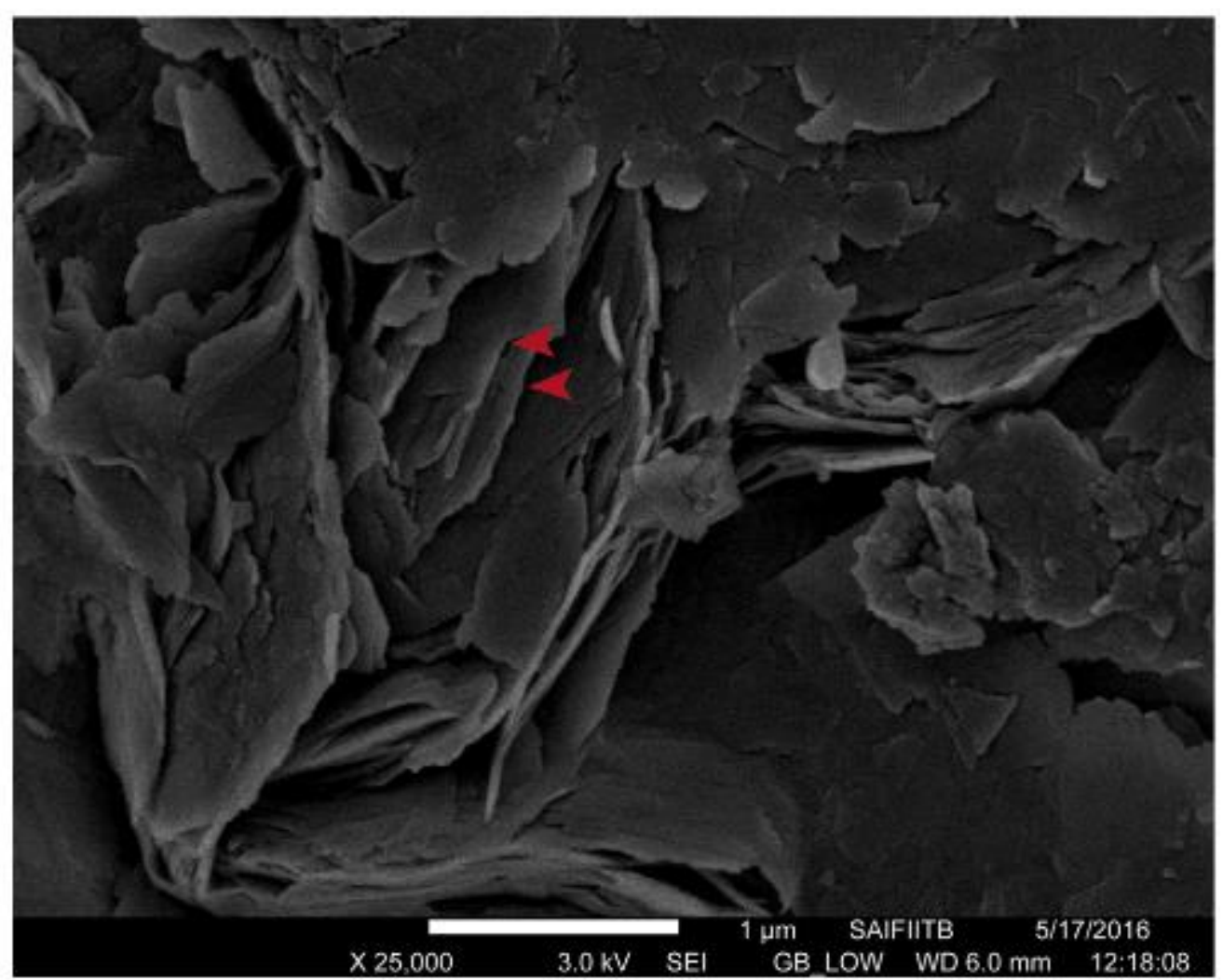

Appendix B: Scanning Electron Microscopy image image of a glauconite pellet in the sample showing well-developed, slightly-sinuous and sub-parallel lamellae marked by red arrows. 

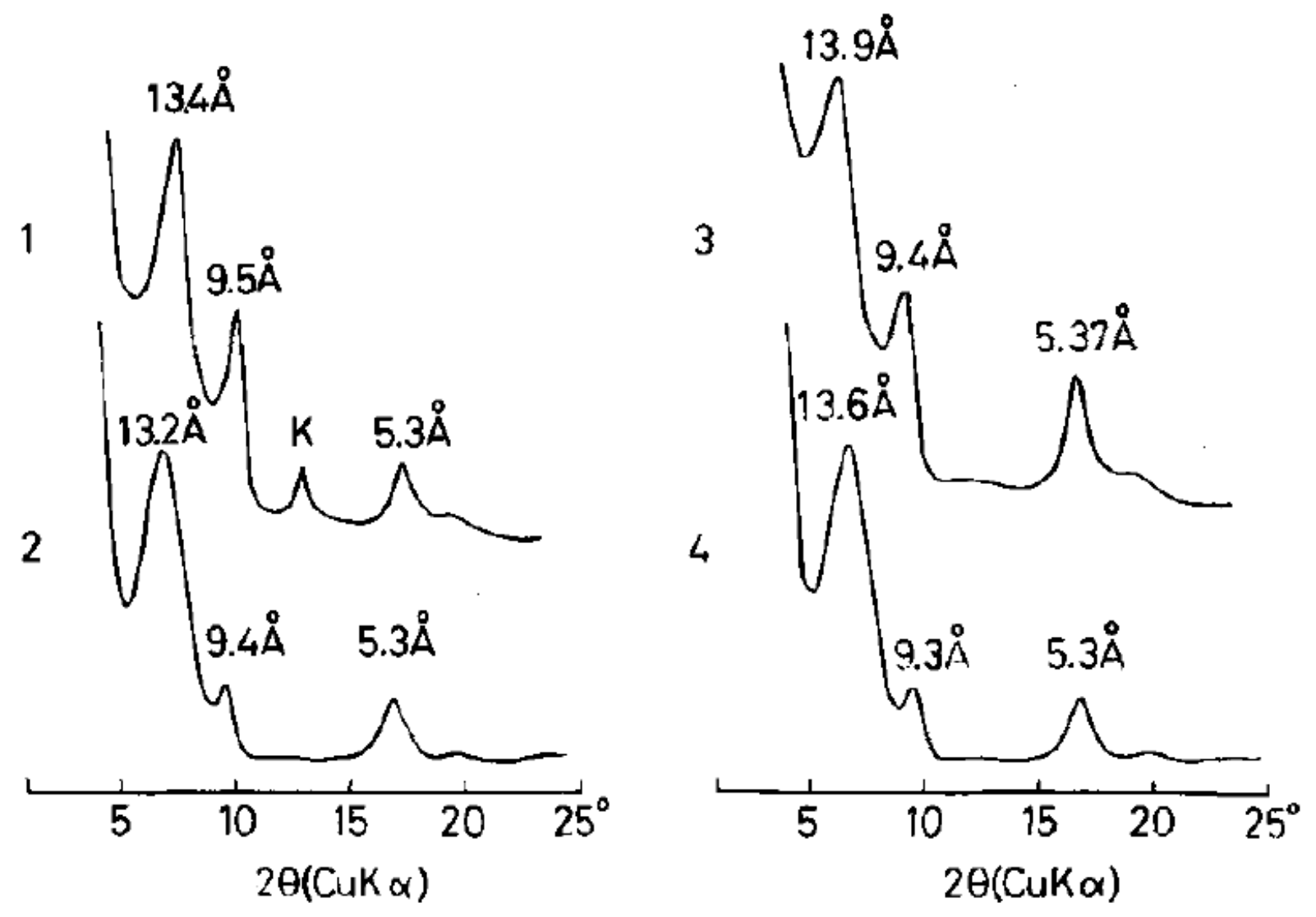

Appendix C: X-ray powder diffraction analysis of mica (Tomita et al, 1988) 

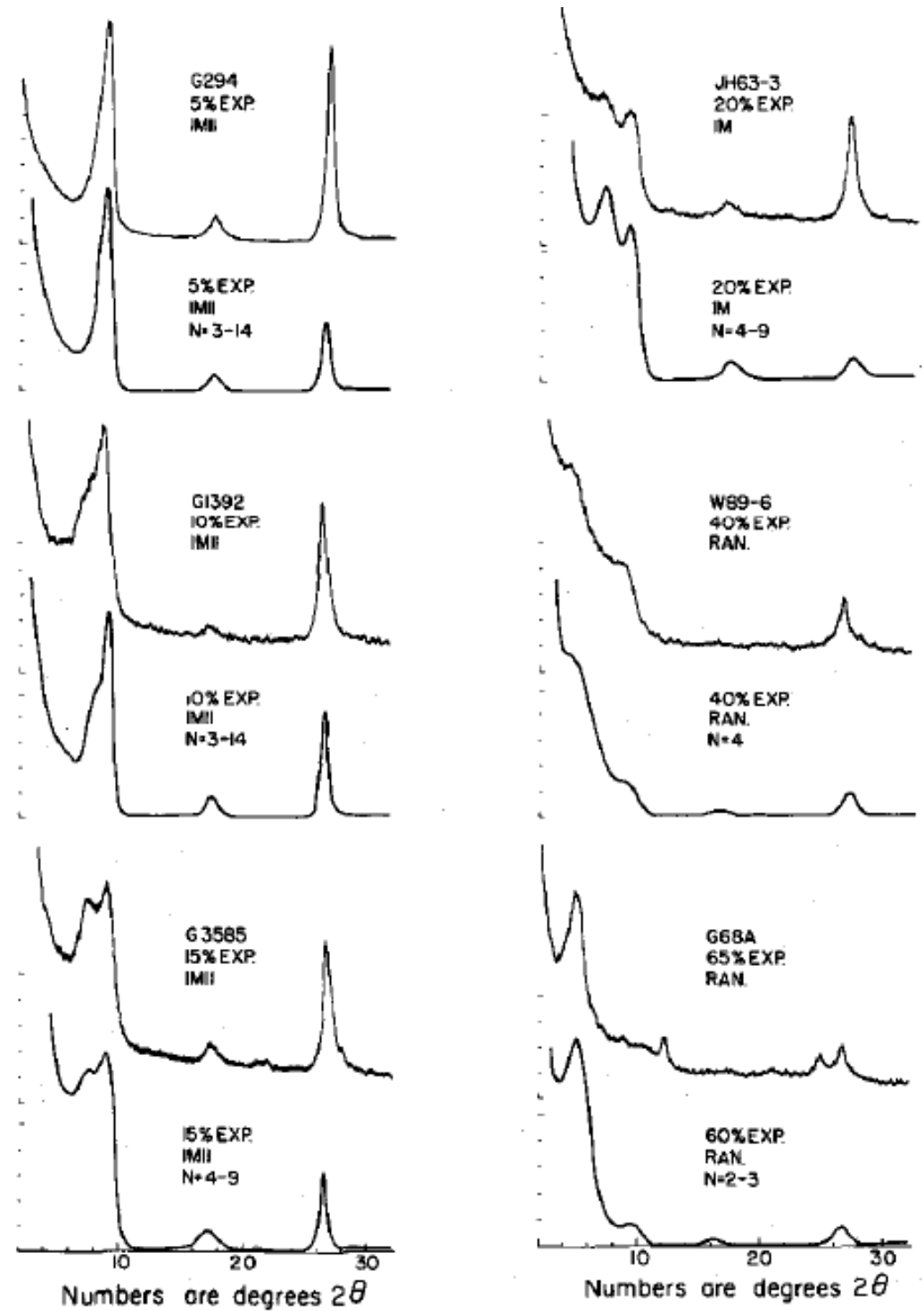

Appendix D: X-ray powder diffraction analysis of non-marine glauconite (Porrenga, 1968)

\section{Copyrights}

Copyright for this article is retained by the author(s), with first publication rights granted to the journal.

This is an open-access article distributed under the terms and conditions of the Creative Commons Attribution license (http://creativecommons.org/licenses/by/4.0/). 